DOI 10.18699/SBB-2020-63

\title{
Роль ключевого белка мисматч репарации млекопитающих MSH2 в эпигенетических изменениях при онкогенезе
}

\author{
Каххарова 3.И.,2*, Грин И.Р., ${ }^{1,2}$ \\ ${ }^{1}$ Институт химической биологии и фундаментальной медицины СО РАН, Новосибирск, Россия \\ ${ }^{2}$ Новосибирский государственньй университет, Новосибирск, Россия \\ *e-mail: zarinkaapels@gmail.com
}

Ключевые слова: неканоническая мисматч репарация (нкММР), эксцизионная репарация ДНК (ЭРО), метилирование ДНК

Мотивация и цุель: У млекопитающих метилирование цитозина играет важную роль в регуляции транскрипции, при эмбриональном развитии и онкогенезе. В последние годы появляется все больше данных о том, что механизм эпигенетических изменений в ДНК на ранних стадиях онкогенеза связан с процессами мутагенеза и репарации, проходящими при участии ферментов эксцизионной репарации ДНК (ЭРО) и неканонической мисматч-репарации (нкММР). В предыдущей работе мы обнаружили [1], что интермедиаты ЭРО и модифицированные цитозины, расположенные по краям протяженного участка одной цепи ДНК (40-400 нуклеотидов) инициируют репарацию и деметилирование всего участка по пути нкММР. Если протяженный участок располагался в промоторной области гена, то опосредованное удаление всех mC путем нкММР приводило к активации экспрессии гена в клетках in vivo, что может объяснить гипометилирование промоторов онкогенов на ранних стадиях онкогенеза. Для изучения взаимосвязи воспалительного онкогенеза с механизмами репарации необходимо установление взаимосвязей между белками, участвующими в процессах транскрипции, репарации и метилирования ДНК.

Meтоды и алгоритмы: Поиск литературы был осуществлен в базе данных NCBI. Для поиска функциональных мотивов белков была использована база ELM. Для построения сети взаимодействия белков была использована программа Cytoscape со встроенной базой данных Spike. Результаты $u$ выводы: Биоинформатическим поиском по базам данных изучено взаимодействие белка MSH2, ключевого участника нкMМР, с белками других клеточных систем: транскрипцией, ЭРО, эксцизионной репарацией нуклеотидов, ДНК-метилазами и другими. Построены сети опосредованных взаимодействий, которые указывают на взаимосвязь процессов метилированиядеметилирования ДНК, что подтверждает гипотезу гипометилирования промоторных областей онкогенов и гиперметилирования промоторов генов онкосупрессоров как разных последствий одного процесса эпигенетических изменений на ранних стадиях онкогенеза с воспалительными процессами.

Финансирование: Исследование выполнено при финансовой поддержке РФФИ в рамках научного проекта № 18-29-07059.

\section{Список литературь}

1. Grin I., Ishchenko A.A. (2016) An interplay of the base excision repair and mismatch repair pathways in active DNA demethylation. Nucleic Acids Res. Vol. 44, P. 3713-3727. 